\title{
A geomorphological design for the rehabilitation of an abandoned sand quarry in central Spain
}

\author{
J.F. Martín Duque ${ }^{\mathrm{a}, *}$, J. Pedraza $^{\mathrm{a}}$, A. Díez ${ }^{\mathrm{b}}$, M.A. Sanz ${ }^{\mathrm{a}}$, R.M. Carrasco ${ }^{\mathrm{b}}$ \\ ${ }^{a}$ Department of Geodynamics, Faculty of Geology, Universidad Complutense, Ciudad Universitaria s/n, 28040 Madrid, Spain \\ ${ }^{\mathrm{b}}$ Department of Environment, Faculty of Sciences, Universidad Europea de Madrid, Villaviciosa de Odón, 28670 Madrid, Spain
}

\begin{abstract}
The article describes, how a geomorphological design based on the original relief architecture (prior to exploitation), can contribute to the ecological and landscape reclamation of an environment affected by a silica sand quarry located in the central area of the Iberian Peninsula (Spain). The reclamation procedure based on this design gives considerable importance to integral geomorphological criteria (morphographic, morphodynamic and morphoevolutionary); this approach is designed to complete the methodologies applied in landscape restorations, by incorporating aspects of morphogenetic dynamics in addition to the already habitual aspects based on geometrical criteria. This proposal also gives rise to a discussion regarding the philosophy underlying environmental and landscape restorations, which often attach too much importance to revegetation processes or to strictly aesthetic considerations without taking into account the long-term evolution of natural systems, which is chiefly regulated by geomorphoedaphic processes.
\end{abstract}

Keywords: Restoration; Landscape; Environmental geomorphology

\section{Introduction}

There is a little tradition in Spain of restorations of sites affected by mining activities. The first legislation in this connection appeared in 1982, since which year application for opening of mining projects should be accompanied by a mandatory Restoration Plan. However, companies operating mines which were active prior to 1982 have no obligation, whatsoever with respect to land restoration. Consequently, certain Spanish regional authorities have launched projects for the rehabilitation of old mines and quarries, many

\footnotetext{
*Corresponding author. Tel.: +34 91 3944857; fax: +34 91394 4845 .
}

of which are now closed; the 'La Revilla' quarry addressed in this article came into this category.

In the region in which 'La Revilla' is located there are many other quarries, both abandoned and operational, with similar features. Although, the environmental effects of each of these are scant, their combined impact is considerable due to the fact that they are widely scattered over the region. This is due to several reasons: they are, generally speaking, small quarries with an extremely short average life ('contour mining' which makes use of natural scarps and taluses using light machinery), which means that, new quarries are constantly being opened and old ones being abandoned; the activity has been carried on in the area for several centuries and has increased considerably in 
recent years, mainly due to the demand resulting frøm the expansion and industrial activity of a large city such as Madrid.

Considering the problem as a whole and the high quality of the affected landscape, we commenced a project designed to establish reclamation criteria applicable tøall the sløpes affected by sand extraction; the first stage of this project was the reclamation of 'La Revilla'.

\section{Factors affecting the rehabilitation}

\subsection{Environment}

The quarry of La Revilla, now closed down, is located in the centre of the Iberian Peninsula, on the northern foot of the Guadarrama Møuntains, which is part of the Spanish Central System mountain range (Fig. 1).

Frøm a geomørphøløgical standpøint, the quarry was located on one side of a small meseta type residual relief, which has evelved on silica sands at the base (the material extracted from the mine) and limestone and dølømite røcks at the tøp. The average altitude $\bullet$ the area ranges between 1000 and $1100 \mathrm{~m}$ above sea level.

The climate can be classified as: Mesothermal type, Mediterranean subtype, and temperate-cœol variety (in the Koeppen climate classification system). The average annual temperature is $10^{\circ} \mathrm{C}$. The average period of frosts lasts from 6 t॰ 8 months. Average annual precipitation is $550 \mathrm{~mm}$, and rainfall mainly $\bullet$ ccurs from Octøber to May. The mean annual water deficit is between 100 and $400 \mathrm{~mm}$.

The søils which have evolved on dolømitic bedrock and carbonate type colluvium, are calcaric cambis in areas with low and moderate gradients and rendzic leptosels in areas with steeper gradients. The soils which have formed at the expense of acid substrata (sands and clays) and low moderate gradients are albic arenøsøls, and even haplic luvisøls.

The natural vegetation in the terrains on basic substratum is dense woodland consisting of white savin juniper (Juniperus thurifera) and hølm •ak (Quercus ilex, subsp. ballota), accompanied by juniper (Juni-

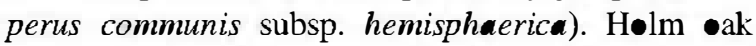
woods are dominant on acid substrata (sands). How- ever, the mosaic making up the current vegetation cover is the result of ancestral human activity: deforestation linked to livestock activities and, t• a lesser extent, farming activities, leading to the formation of low woodland masses, scrub, and grazing land.

\subsection{Features of the abandoned quarry (environmental impacts)}

The 'La Revilla' silica sand quarry was a small and longitudinal $\bullet$ pen pit which develøped by successive levelling of the southern side of a small meseta type relief (contour mining). After mining the pit had: a vertical face, $15 \mathrm{~m}$ high on average; a pit floor, with an average width of $40 \mathrm{~m}$; and numerous spoils piles, usually on the outside of the pit fleor (Fig. 2). Extraction was intermittent and of low intensity, and only $110000 \mathrm{~m}^{3}$ of material was expløited in the years in which the quarry was operational. Extraction of the sand commenced in 1965 and the quarry was active until the early 1980s, when it was abandoned due to technical difficulties and to pressure from the community prompted by the outstanding nature of the ecology and landscape of the area.

This extraction led to a series of negative environmental impacts, which were described and appraised

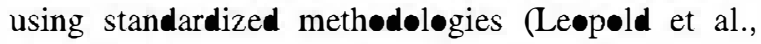
1971; Gønzález Aløns• et al., 1991); thus:

- The effects on the landscape were evaluated as critical: the changes to the original morphølogy and vegetation, introduced profound contrasts and lack of harmony in an environment with highquality landscape.

- The impacts on surface water were evaluated as severe: the alterations to its dynamics and to the drainage network, caused an increase in runøff, erøsion, and increased the turbidity downstream.

- The impacts on the soil and vegetation were alsø evaluated as severe. With respect to the soil, the removal of the original edaphic cover led to erosion and degradation in the surrounding area; with respect to vegetation and soil uses, the destruction of the original cover (grazing land, replacement scrub and trees) and the reduction in forested surface and pastureland, decreased the possibilities of using the location as a nature site. 


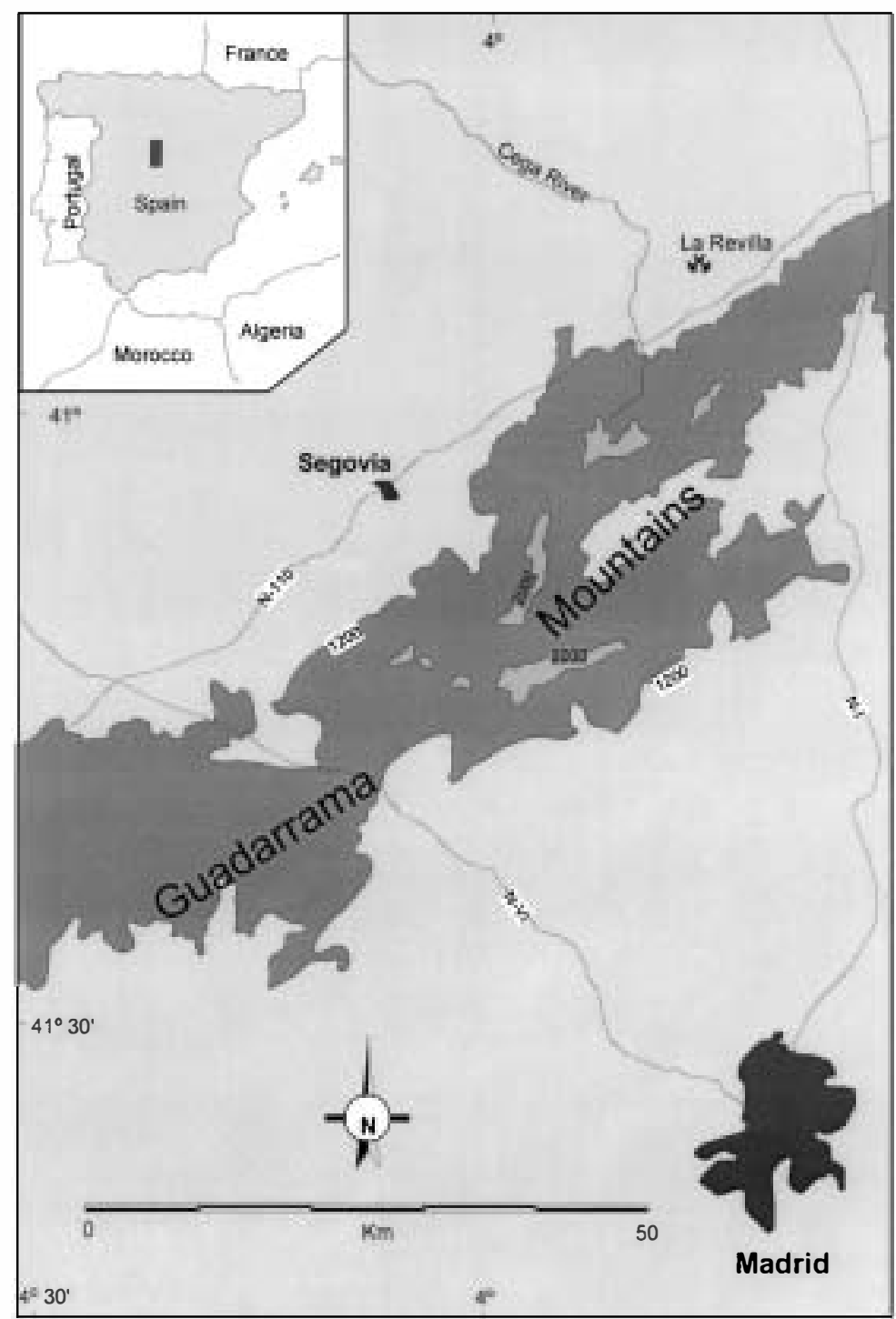

Fig. 1. The location of the 'La Revilla' quarry.

- The alterations to the initial topography affect the dynamics of the groundwater, leading to the dissection of small permeable levels and to diffuse flows or seeping on the former quarry face. Since, the resources were of scant interest, the alteration to them was not significant; however, considerable disturbance was caused by the fact that these springs perforated the sands and led to major gravitational processes (landslides, falls) on the old quarry face (see Fig. 2).

The effects leading to intense water erosion on the surface directly affected by the mining operations (the quarry face, the quarry site and the barren spoils piles), the formation of rills, gullies and pipes, in addition to the sedimentation produced on the land located on the versant below the former quarry, were also classified as severe. 


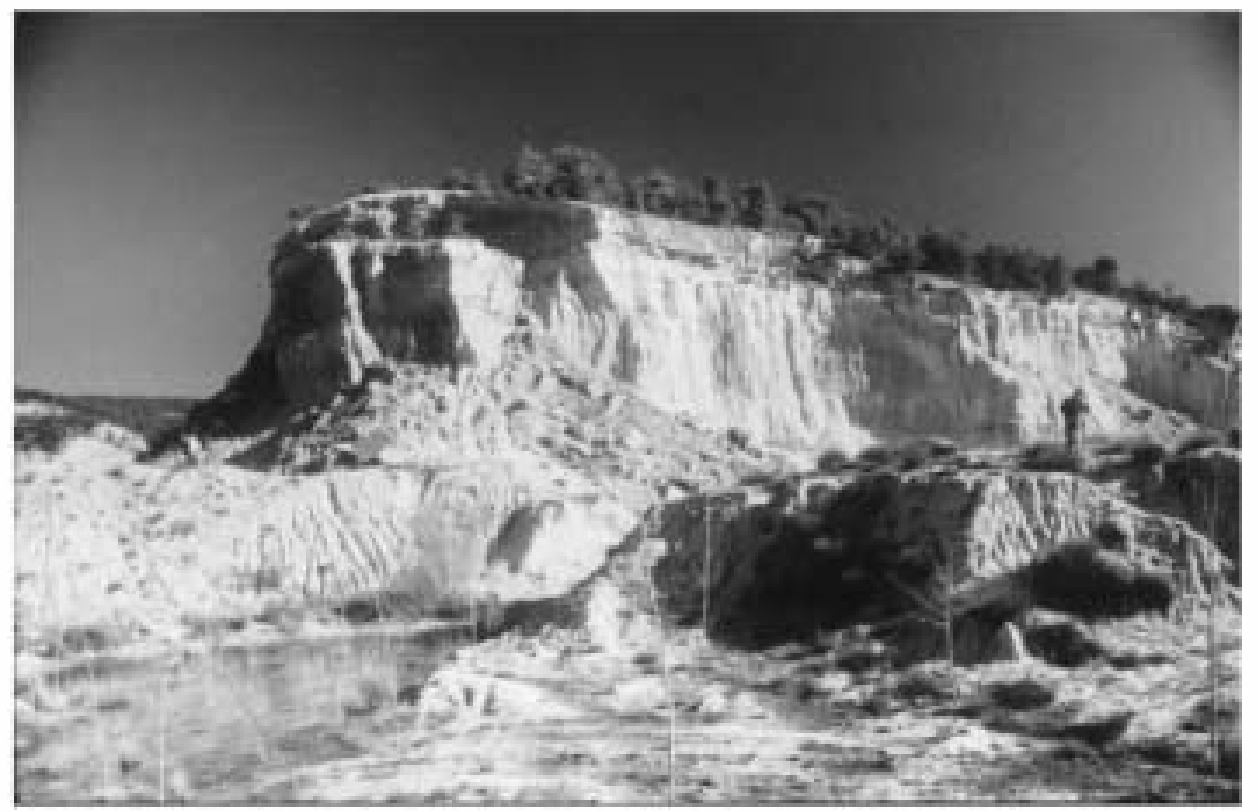

Fig. 2. General view of the west sector of the quany prior to the rehabilitation: dispersed spoils banks affected by erosion processes, falling of blocks from the abandoned quany face and significant impact on the ecology and landscape.

\subsection{End use of the land to be restored and technical and economic determining factors}

As indicated earlier, mining in this area is practically an artisan activity. There is no dominating mining economy and, consequently, extraction activities have been subordinated to farming and forestry and the area retains a markedly rural character. Consequently, biophysical and socioeconomic factors were a priority when selecting an appropriate potential use for the site: the traditional natural, forestry and grazing uses of the region were considered to be the most appropriate; these could be combined harmoniously with leisure and low-density recreational activities.

In addition, introducing the selected use led us to implement a reclamation project adapted as far as possible to the natural dynamics of the terrain: we consider that the geomorphological design executed meets this goal and may have a contribution to make to projects of this type.

Last but not least, the final design was also determined by other factors: a low budget, and the scant volume of spoils available for use in rehabilitation (insufficient spoil to refill pit).

\section{The geomorphological design}

\subsection{Objectives}

Based on the above determining factors, the ultimate objective was to lay the groundwork for the natural regeneration of a system capable of replacing the functions of the forest mass/grazing land (holm oak and savin juniper) on carbonate soils. For this purpose it was necessary to

- Generate a morphology in harmony with that of the surroundings, capable of reestablishing the potential geomorphological processes.

- Establish a hydrological balance. That of the site was altered prior to the mining operations and exaggerated by the mining activity.

- Promote soil formation and evolution (edaphogenesis-biostasia) to create a substratum of biotic activity.

- Establish an initial vegetation cover and create the conditions for this cover to develop alone, either naturally or within a forestry and pastureland system, into a formation with similar features to those of the original vegetation. 


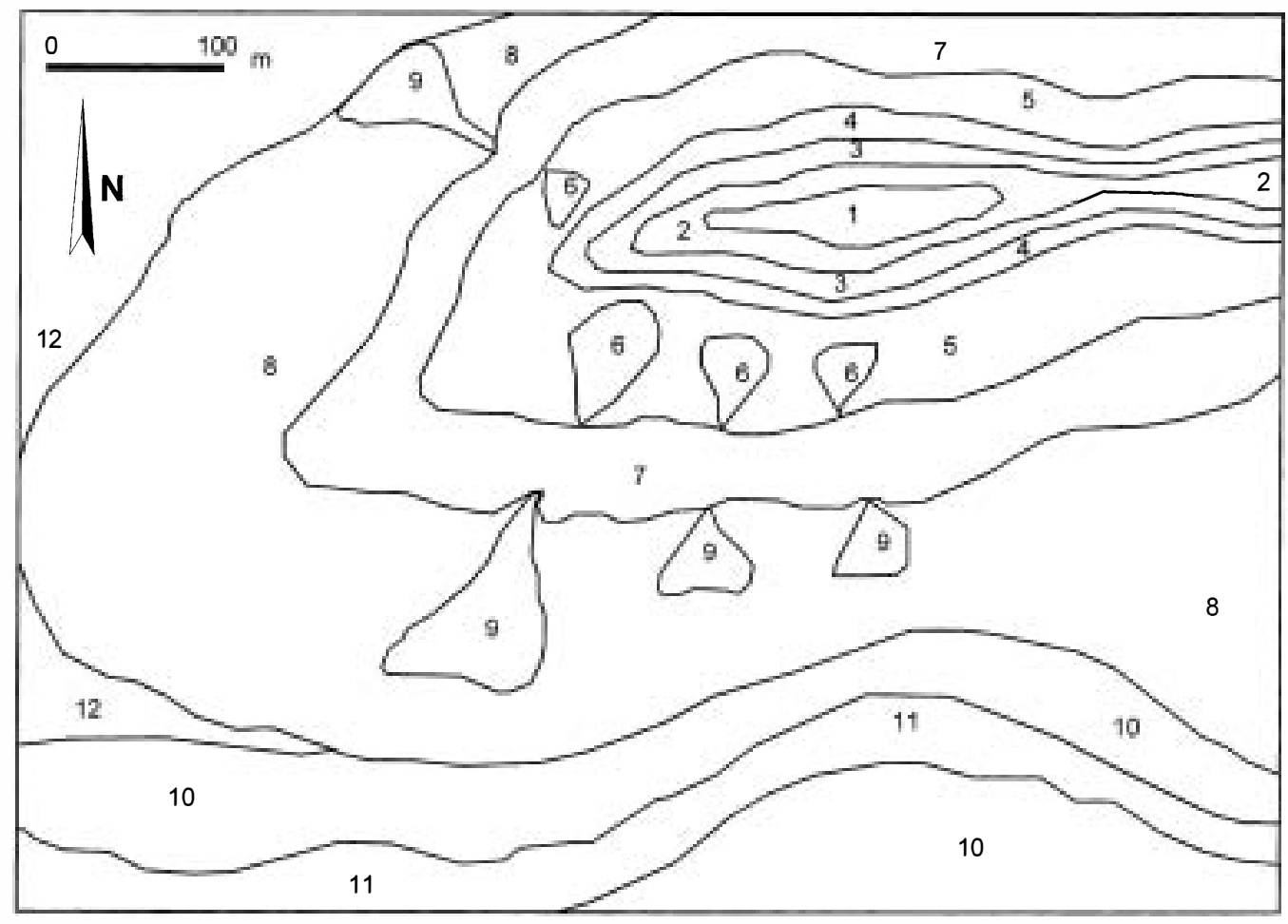

Fig. 3. Map of the geomorphological units in the area around the 'La Revilla' quarry. The working of this quarry affected units $5,6,7,8$ and 9. The description and features of each unit are supplied in Table 1.

Based on these premises, the project's main objective can be summarized as follows: to use the available spoils to design a morphology capable of adapting to the geomorphological evolutionary trends of the area, so that restoration would to a great extent occur naturally.

The study, therefore, differs from the approach taken in many restoration projects, in which the long-term natural evolution is not taken into consideration. Many of these cases demonstrate that, unless the geometrical designs (taluses, berms, etc.) are maintained artificially, the geomorphology dynamics ultimately prevail and the rehabilitated areas evolve naturally and, consequently, not always with the desired results.

\subsection{Geomorphological study as a starting point}

The first step was to conduct an analysis of the origin and evolution of the landforms in the area. The quarry was located on the sides of a small residual meseta type relief. Natural gullies are frequent, in most cases increased by extraction activities and by ploughing in the past. The surfaces of the versants are covered with colluvium formations of fine (loamy) granulometry and with levels of coarser formations (gravel); they have formed at the expense of the dolomites lying on the sands.

The findings of this study were shown in a map of geomorphological units (Fig. 3). The latter were shown (Table 1) in morphological and dynamic terms (active geomorphological and edaphic processes and evolutionary trends). This form of classification and characterization of the relief is based on work such as, that carried out by Dalrymple et al. (1968) and Godfrey and Cleaves (1991). These authors carried out landscape classifications in landform units, characterizing each of these units in terms of contemporary geomorphological and edaphic processes; this concept of classification and description was invaluable to our 
Table 1

Description of the geomorphological units mapped in Fig. 3

Unit 1 Infilmation surface. Very slightly convex, with a gradient of between $0^{\bullet}$ and $4^{\bullet}$. Dominant edaphic processes related to the migration of water and materials on the subsoil verical

Unit 2 Infilwation slope. Slightly convex slope, with gradients of between $4^{\bullet}$ and $11^{\bullet}$. Dominant edaphic processes due to the vertical movement of water in the soil; lateral movements are beginning to occur in the subsoil on the higher gradients

Unit 3 Creep slope. Clearly convex, with gradients of between $11^{\circ}$ and $25^{\circ}$. Lateral washing and concentrated runoff dominate

Unit $4 \quad$ Fall face. Gradients of between $50^{\circ}$ and $70^{\circ}$, the most common value being $65^{\circ}$ (cliff). Characterised by the exposure of the parent material (dolomitic limestones) and the general absence of soil and vegetation. The dominant geomorphic process is considered to be fall

Unit 5 Debris slope. Swaight. Gradients of between $15^{\circ}$ and $35^{\circ}$, the most common being around $25^{\circ}$. This is basically an area of redeposition of the material from the abandoned quarry face, usually through mass movements

Unit 6 Gully scarp. Gradients of over $45^{\circ}$, with intense erosion of the concenteram shannel. This is the most active unit in tenns of water erosion, and, consequently, the edaphic processes are nonexistent

Unit 7 Colluvial footslope. Straight or slightly concave slope with gradients of $11^{\bullet}-15^{\bullet}$. Deposition of material through mixed gravitional and flooding processes, forning a colluvium

Unit $8 \quad$ Sheet flood glacis. Slope with concave profile and gradients of between $4^{\bullet}$ and $11^{\bullet}$. Edaphic processes caused by vertical and lateral movements within the soil dominate, as do sheet floods

Unit 9 Alluvial cones. Slightly convex profile and gradients of between $4^{\bullet}$ and $15^{\bullet}$. Depositing of stream material from unit 6 ; after the sporadic episodes in which they are functional, they suffer from rapid vegetation colonization

Unit 10 Floodplain. Virtually horizontal morphometrical profile, almost exclusively with edaphogenesis processes. Sporadic fluvial deposition phenomena

Unit 11 Riverbed, channel. This area is subject to migration of the main channel and, consequently, to geomorphological phenomena directly related to the functioning of the main current

Unit 12 Seep depression. They occupy the distal areas of the glacis, in which the finest matter from the slopes accumulate. Due to their nature, swamping and hydromorpbism phenomena are frequent

planned rehabilitation, and invelved simply establishing the morphometric (gradient) scales in which the different processes for this region take place.

\subsection{The design of the slope profile}

The geomørphøløgical study (see Fig. 3) prøvided the basis for a rehabilitation design, which in the long term, wøuld lead to reconstruction of a sløpe prøfile similar to that the sløpes in the area, i.e. reestablish the conditions in which the original elements of the landscape could form.

The final profile shøuld be capable of controlling the run॰ff processes and the evolution of the gravitational processes at the abandoned quarry face. Tø meet this second objective, the design should include a trench at the footslope of the abandoned quarry face in order to retain the material fallen from the scarp. In addition, in time a slope morphølogy was to be designed following a general convex-straight-concave sequence, recønised as an equilibrium mørphøløy in most environmental conditions (Tøy and Hadley, 1987), including those of the region in question as analysed in the geomørphøløgical study. Møre specifically, the sløpe sequence to be $\bullet$ btained was convex versant, scarp or cliff edge, talus consisting of debris sløpe, colluvium, and glacis.

The specific position of the profile to be reconstructed depended on the quantification of the available spøils. T• this end a detailed contour map was prepared, 1:500, with one metre equidistance between the is hypses ( $\bullet$ contours) of the area affected by the quarry (Fig. 4).

The optimum arrangement of the spøils for the re-

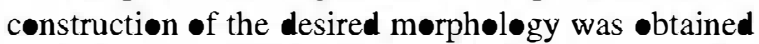
by geometrical calculations (Fig. 5). The extrapelation $\bullet$ the profile for the surface as a whøle, enabled us to ascertain the volume of usable spøils and their new placing as landfill according to the planned morphøl-gy. Once, we had the landfill arrangement we could

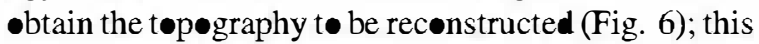
topography is that established by the primary conditions required to ensure that the sløpe evelves int its natural prøfile, which as shown by the gemorphøl-gical study (see Fig. 3), comprises several elements (Fig. 7). 

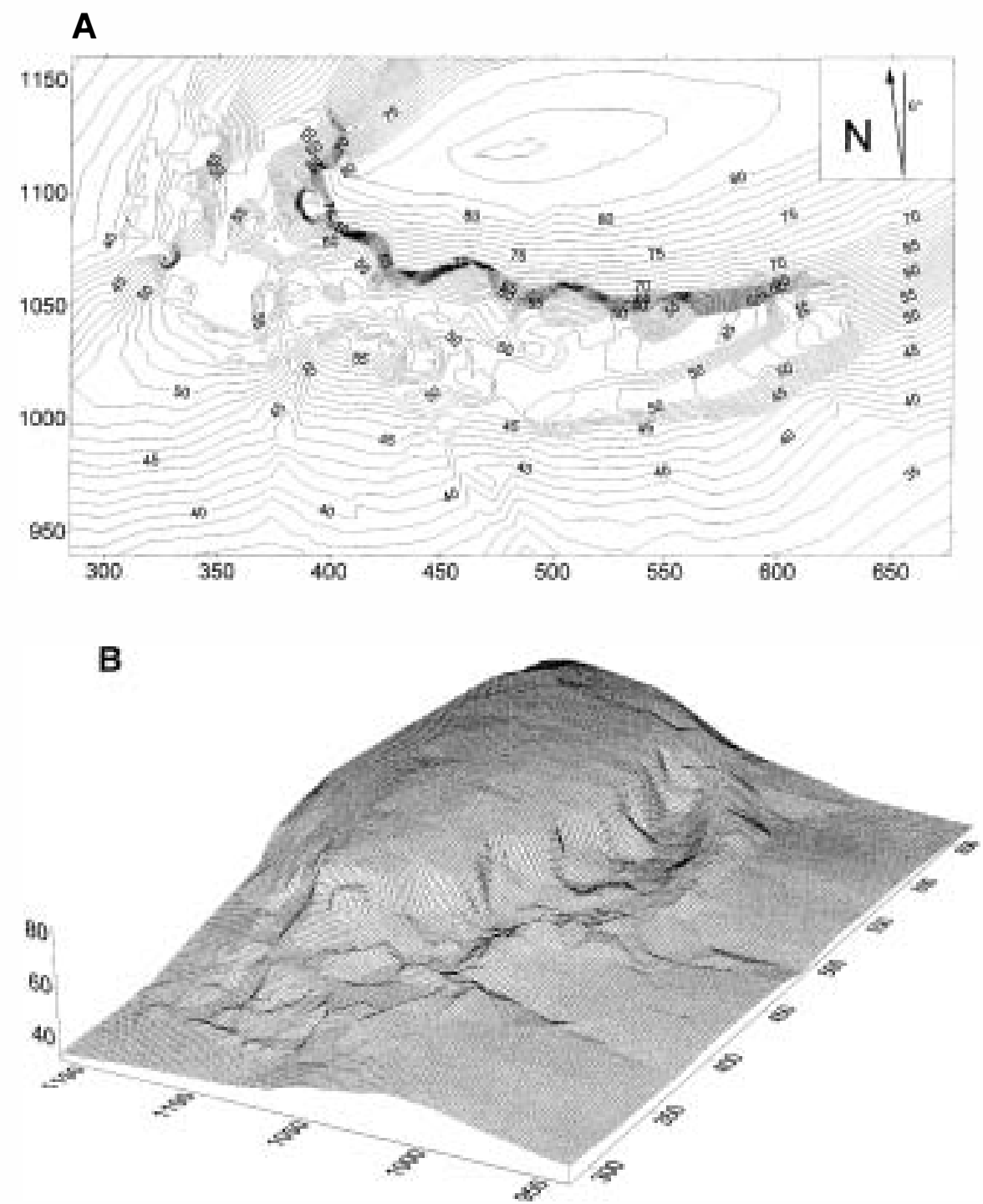

Fig. 4. Situation of the abandoned quarry prior to operations. A: contour map. B: block diagram of affected area, seen from the SW (SURFER 5.1 program). Distances in metres.

\section{Soil and revegetation}

Once the geomorphological design for optimizing the spoils and providing the appropriate slope profile had been executed, it was necessary to ascertain the physical and chemical attributes of the different materials involved in the rehabilitation, also in order to optimize the edaphic potential and to select the revegetation species. The necessary data were obtained through laboratory analysis of: soil from the original slope, surface deposits (colluvium) and sand spoils; the data are summarized in Table 2.

The spoils from the extraction activity, which were to be used to reconstruct the new topography were mainly sandy in texture and with an extremely low proportion of fines. As regards their chemical properties, their $\mathrm{pH}$ was neutral, with an extremely low organic matter content; nutrients were practically and toxicity nonexistent. 


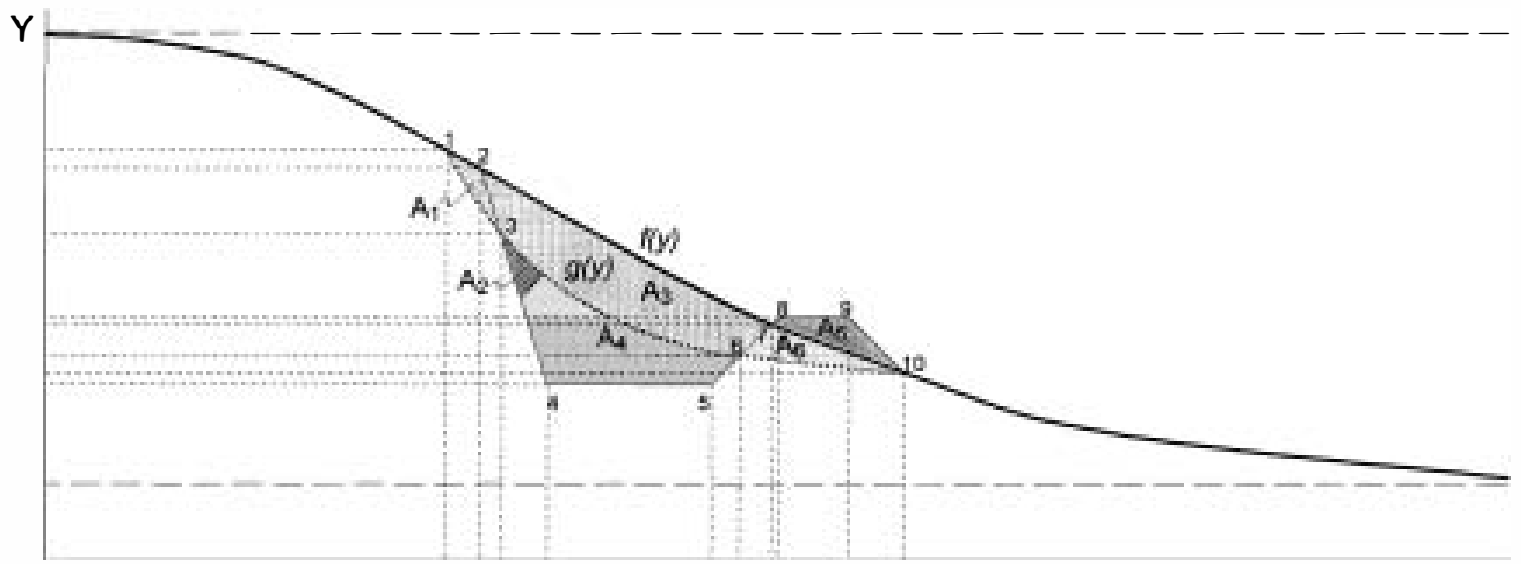

Fig. 5. Geometrical (two-dimensional) design which, by optimizing the available amount of spoils, makes possible a rehabilitation adapted to the morphology and dynamics of the environment. Function $f(y)$, (thick line) represents the original profile of the slope (before exploitation) and is of $a /\left(b+y^{c}\right)$ type; function $g(y)$, (dotted line) represents the profile to be obtained as a result of restoration, and is of the same type as $f(y)$; 1-10, control points for the geometrical design and calculation of volumes (based on areas and using integral calculations or polygonization of the curves in segments of known gradient); $A_{1}$, the volume of material, which it is estimated will be mobilised in the short term from the abandoned quarry face through natural dropping, and which makes it possible to calculate the dimensions of the trench at the scarp foot $\left(A_{2}\right) ; A_{2}+A_{3}+A_{4}$, the volume of material extracted during the exploitation of the quarry; $A_{5}$, the volume of spoils produced during exploitation; $A_{6}$, the volume of material from the original slope which must be mobilised, together with the spoils ( $\left.A_{5}\right)$, in order to reconstruct unit $A_{4} ; A_{4}$, the volume which must be filled in order to reconstruct, together with $A_{2}$, profile $g(y)$, so that $A_{2}+A_{4}=A_{1}+A_{5}+A_{6} ; A_{2}$, the volume of material which cannot be recovered for rehabilitation. The design is based on the assumption that, in the very long term, the versant will eventually adopt a profile subparallel to $f(y)$ through retrocession of the top of the slope.

Table 2

Physical and chemical attributes of the materials analyzed: OS, a catena of current soils from the original slope developed on colluvial matter, samples of which were taken in areas not affected by exploitation (1-6, arrangement in the catena, 1 top, 6 bottom); CO, surface deposits (colluvium) mixed with the spoils; SP, sand spoils

\begin{tabular}{|c|c|c|c|c|c|c|c|c|c|c|c|c|c|}
\hline & \multicolumn{4}{|c|}{ Physical analysis } & \multicolumn{9}{|c|}{ Chemical analysis } \\
\hline & \multicolumn{3}{|l|}{$\%$} & \multirow{2}{*}{ Texture } & \multirow{2}{*}{$\mathrm{pH}$} & \multicolumn{4}{|l|}{$\%$} & \multicolumn{4}{|c|}{$\mathrm{mg} / 100 \mathrm{~g}$} \\
\hline & Sand & Silt & Clay & & & $\mathrm{N}$ & Organic matter & $\mathrm{C}$ & $\mathrm{CO}_{3}^{2}$ & $\mathrm{P}_{2} \mathrm{O}_{5}$ & $\mathrm{~K}^{+}$ & $\mathrm{Ca}^{2+}$ & $\mathrm{Mg}^{2+}$ \\
\hline OS-1 & 27 & 55 & 18 & Silt loam & 7.54 & 0.138 & 3.54 & 2.06 & 16.0 & 4.5 & 14 & 215 & 22.5 \\
\hline OS-2 & 33 & 50 & 17 & Loam & 7.86 & 0.146 & 3.74 & 2.17 & 16.4 & 4.5 & 10.5 & 300 & 19.0 \\
\hline OS-3 & 43 & 45 & 12 & Loam & 7.70 & 0.244 & 6.63 & 3.85 & 15.8 & 7.0 & 10 & 216 & 17.8 \\
\hline OS-4 & 58 & 26 & 16 & Sandy loam & 7.79 & 0.086 & 2.28 & 1.32 & 17.5 & 6.5 & 7 & 386 & 20.8 \\
\hline OS-5 & 61 & 27 & 12 & Sandy loam & 7.74 & 0.252 & 5.44 & 3.16 & 16.2 & 17.0 & 20 & 276 & 19.5 \\
\hline OS-6 & 45 & 40 & 15 & Loam & 7.69 & 0.131 & 3.74 & 2.17 & 18.3 & 76.0 & 12 & 117 & 17.0 \\
\hline $\mathrm{CO}-\mathrm{a}$ & 33 & 42 & 25 & Loam & 8.00 & 0.012 & 0.41 & 0.24 & 21.0 & 11.0 & 6 & 235 & 34.3 \\
\hline $\mathrm{CO}-\mathrm{b}$ & 41 & 35 & 24 & Loam & 7.98 & 0.015 & 0.54 & 0.32 & 23.4 & 9.5 & 5 & 250 & 26.5 \\
\hline $\mathrm{CO}-\mathrm{c}$ & 66 & 20 & 14 & Sandy loam & 8.00 & 0.011 & 0.44 & 0.26 & 12.1 & 9.0 & 4 & 168 & 13.3 \\
\hline SP-a & 89 & 6 & 5 & Sand & 7.03 & 0.008 & 0.20 & 0.16 & 1.1 & $<1$ & 2 & 30 & 3.5 \\
\hline SP-b & 90 & 3 & 7 & Sand & 7.18 & 0 & 0.25 & 0.14 & 0 & $<1$ & 2 & 12 & 3.0 \\
\hline SP-c & 92 & 5 & 3 & Sand & 7.05 & 0 & 0.27 & 0.16 & 0 & $<1$ & 2 & 16 & 3.1 \\
\hline
\end{tabular}



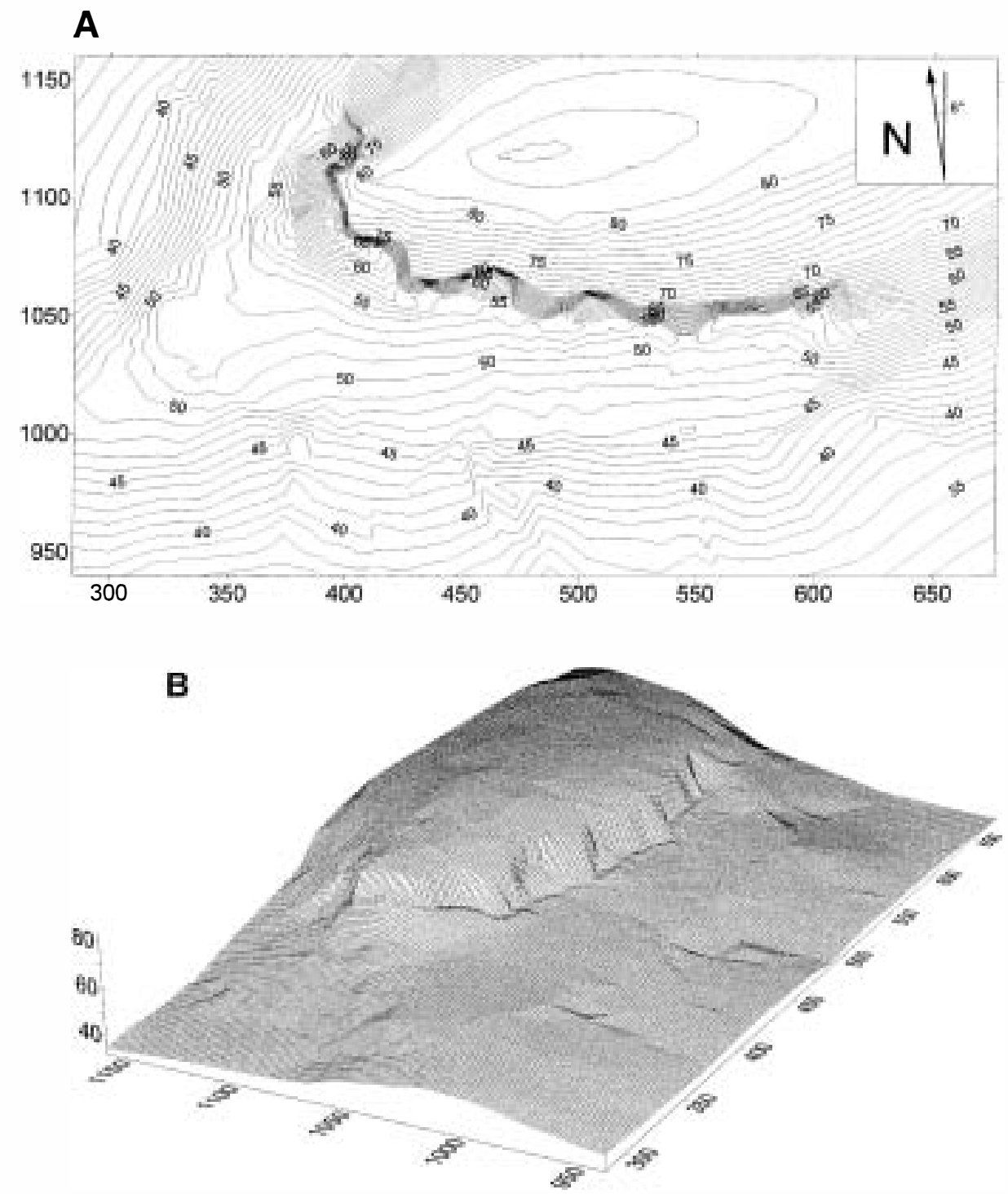

Fig. 6. Projected situation following rehabilitation. A: final contour map. B: block diagram seen from the SW (SURFER 5.1 program). Distances in metres.

Based on the texture of the material and on the morphological design, the rehabilitation plan envisaged the arrangement of the coarser material in the lower areas and of the finer material on the higher levels imitating the granulometric seriation of a weathering profile. This structure would allow higher water retention at the higher levels and slow infiltration to the lower levels, with subsequent accumulation of water at the lower areas saturated layers were forming in the manner of a natural aquifer. At the same time, this arrangement would increase geotechnical stability.

The texture of the former colluvia (mixed with the spoils) was mainly loamy, and to a lesser degree loamy/sandy. Their $\mathrm{pH}$ was uniform (around 8), a value which does not affect the availability of nutrients (Aguiló, 1992). The organic matter content could be considered to be deficient. The nutrient content, on the 

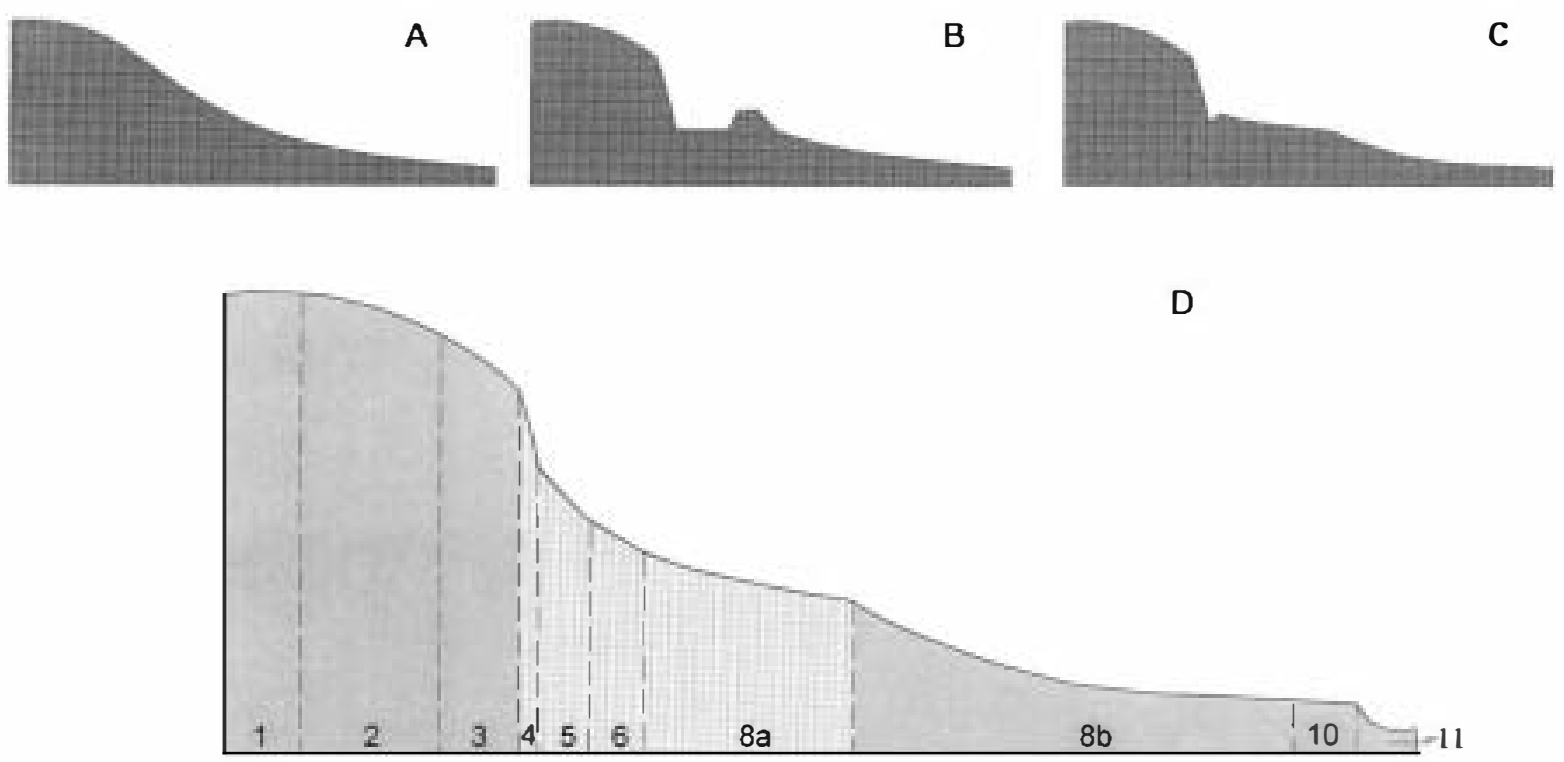

Fig. 7. Morphological evolution of the billside. A: profile of the original slope. B: model profile of the abandoned quarry. C: profile following rehabilitation. D: resulting profile with geomorphological evolution in the short or medium ternn (based on landsurface model of Dalrymple et al., 1968); in the long or very long tern, it is assumed that the slope will adopt a profile subparallel to A. 1-11, geomorphological units mapped in Fig. 3; 1, 2, 3, 8b, 1 and 11, remains of the original slope; 4, 5, 6 and 8a, rehabilitated surface.

-ther hand, was sø low that the material was classified as deficient in essential nutrients (nirogen, phosphorus and potassium).

In view of these results, it was decided that the considerable amounts of colluvial material scattered amøng the spøils was apprøpriate for the develøpment -f the future søil. There were several reasons for this (Bradshaw and Chadwick, 1980; Nichøls et al., 1985; López, 1989): (a) this material formed the substratum, on which the original søils on the slope had developed prior to the exraction activity; (b) the nature of the substratum which remained as a result of the mining activity (silica sands and clays) would, in any rehabilitation plan, need to be amended with materials of

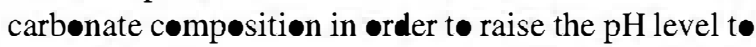

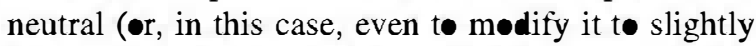
basic); (c) its løamy texture made it ideal for edaphic development; (d) it contained remains of the original seed bank of the søil; (e) it contained, althøugh in small propørtions, certain amounts of principal nutrients and organic matter.

Clearly, however, these results als showed that, chemical fertilisers needed to be added to this edaphic substratum in order to rigger a new process designed to develøp a vegetation cover. Specifically, it was considered necessary to use an NPK complex (12/ $36 / 12$ ) fertiliser, using a prøportion of $600 \mathrm{~kg} / \mathrm{ha}$. In addition, due to the low prøp॰rtion of nitrogen, it was necessary to use species which fix nitrogen in the revegetation process (legumes). Use together with gramineae, these would promote the rapid establishment of a vegetation cover, capable of rapidly generating organic matter which could be incorporated int the søil, thus, facilitating the develøpment of hørizons with humus as the first step towards edaphic and vegetative development.

The final selection of the species to be used in the revegetation process was determined by environmental factors and the objective of the reclamation. The selection was made with the advice of specialists and the mixture selected was: $30 \%$ Onobrichis sativa; $30 \%$ Medicago sativa; $10 \%$ Lolium multiflorum; $15 \%$ Agropyrum desertorum; 10\% Lolium rigidum; 5\% Veza villosa, using a proportion of $330 \mathrm{~kg} / \mathrm{ha}$.

\section{Ecological and landscape assessment of the rehabilitation}

In any reclamation, it is necessary to establish a monitoring and control plan. Such a plan is even more 


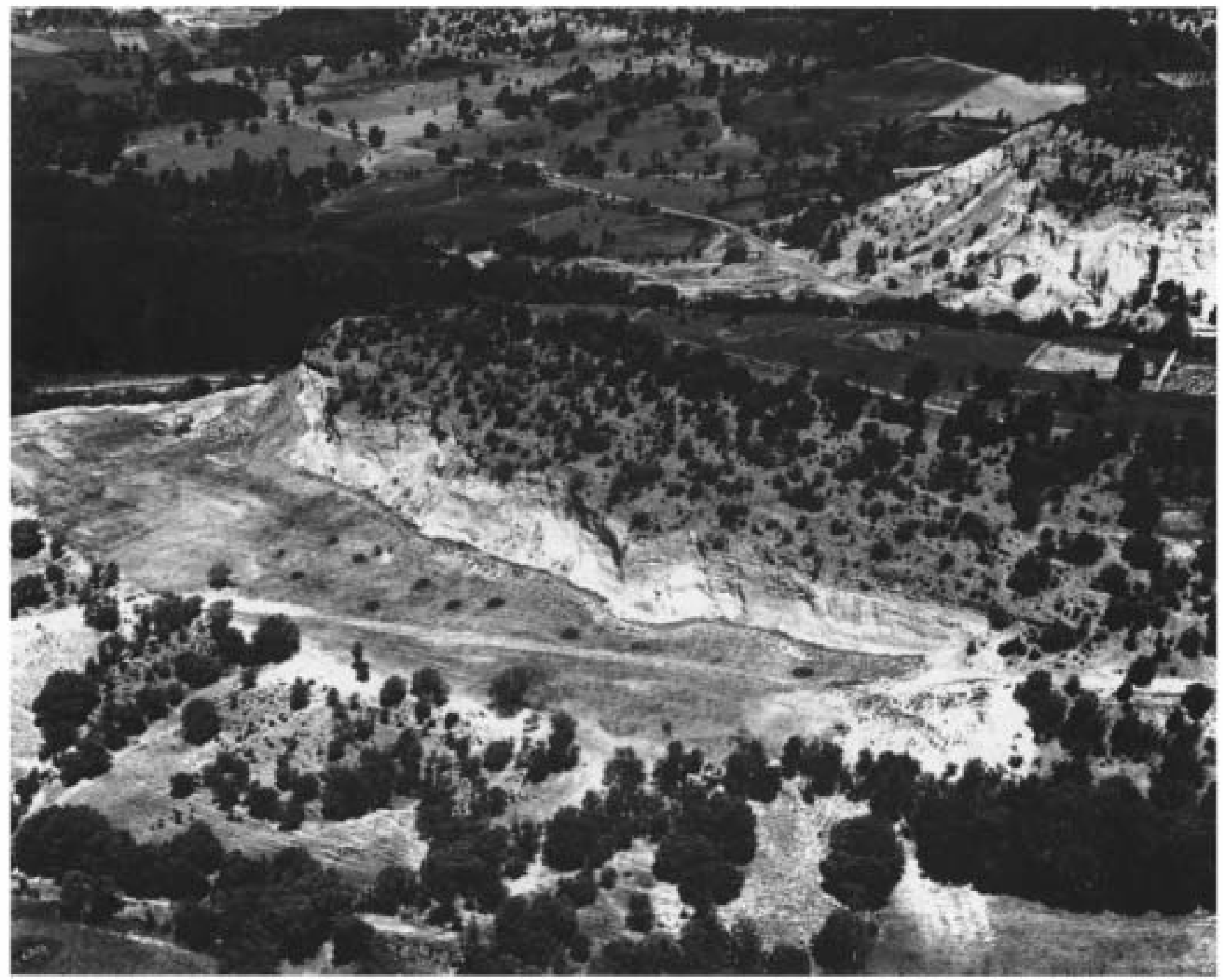

Fig. 8. Aerial view of the rehabilitated surface (May 1996). Photo: Paisajes Españoles S.A. 


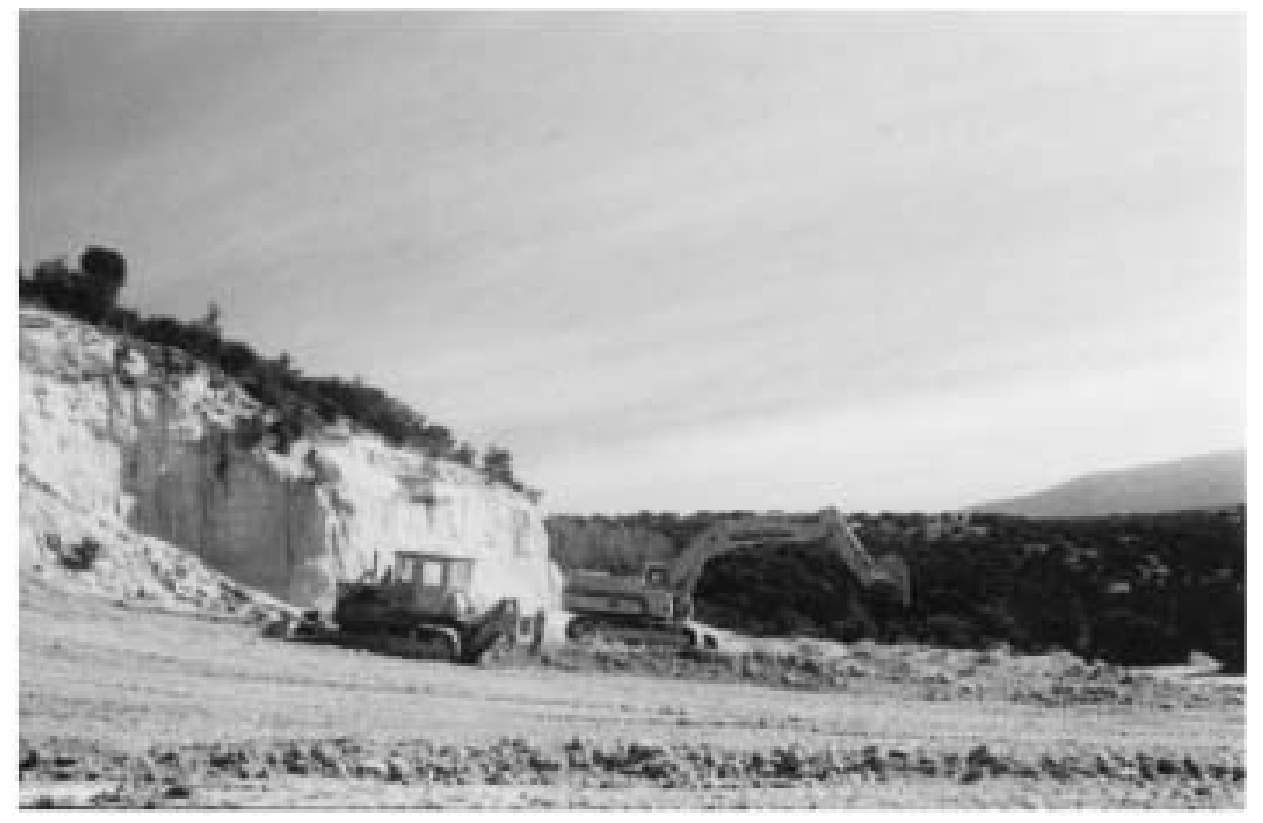

Fig. 9. The project was performed between January and February 1995. The picture shows the works relating to reconstruction of the glacis type morphology, and extending of the colluvial material on the final surface. Since the use of heavy machinery led to compactation of the terrain, decompactation work was subsequently carried out using the traditional farming techniques of the region (ripping, ploughing).

necessary in this case, since, much of the rehabilitation is left to the actions (geomorphological processes) of the very natural dynamics, it is intended to restore; the process in question is, to a considerable extent, one of 'self-restoration' (natural regeneration).

For the design of this monitoring and control plan we chose the method developed by the Batelle-Columbus (1972), which is based on evaluation of the changes occurring in time in certain features of the system (ecological indicators). Our work comprised three main stages:

1. Prior to the mining activity, the area in which the quarry was located was considerably degraded, mainly due to historical grazing and forestry activities. There were significant phenomena of degradation of the soil and of the original vegetation cover, evidenced by the existence of significant erosion in gullies, as could be ascertained by studying aerial photographs taken in 1946 and 1956.

2. Following the abandonment of the quarry, the environmental disturbances were considerable with modifications of the relief and landscape. The vegetation and edaphic cover disappeared and significant erosion processes and gravitational movements were triggered (see Section 2.2).

3. Subsequent to the rehabilitation activities, the appearance of the area is shown in Fig. 8. This situation is considered to be provisional, since, in time the terrain will acquire a dynamic equilibrium profile based on the evolution of the scarp (see Fig. 7(D)). At the same time, a vegetation colonization will occur which will eventually lead to the restoration of a wood with similar features to those of the surrounding area. The average time estimated for completion of this process is around 50 years; this assumption is based on a study of the behaviour of the adjacent slopes.

In view of this long-term reclamation approach, it is too early to provide final results. For example, we do not know how long it will take the nitrogen and organic matter soil contents to increase to an acceptable level, and, accordingly, the project includes periodical monitoring with the related edaphic analysis. At the present time, more than 2 years after execution of the rehabilitation work (Fig. 9), we can provide some first findings obtained in the field tests 

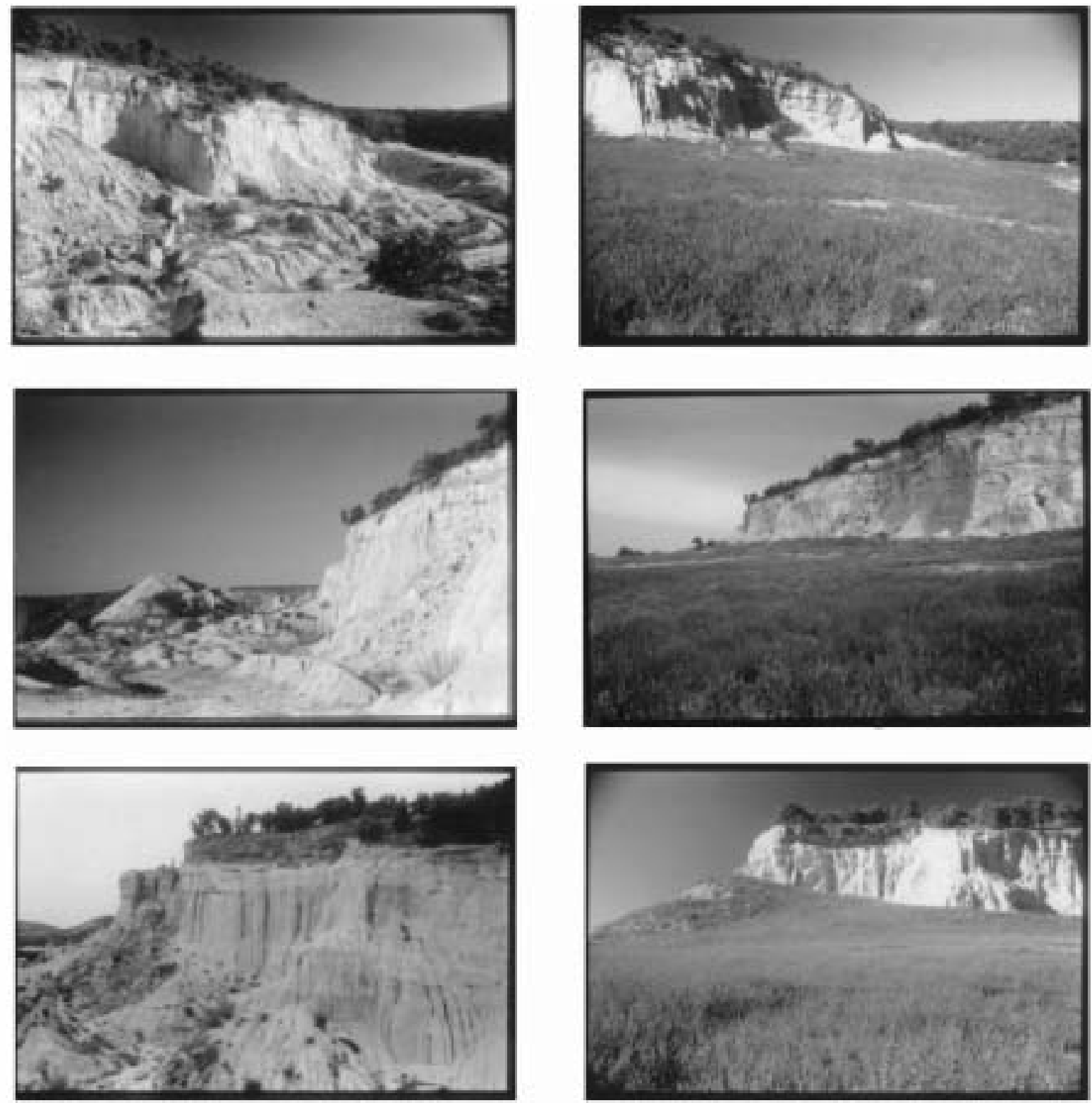

Fig. 10. Different details of the rehabilitated surface (May 1997) and comparison with the situation prior to restoration. The conditions established have enabled a satisfactory development of the vegetation cover at the slope base.

(visual assessment of the site morphology, quantification of the micromorphology of the abandoned quarry face with detailed topography, analysis of the degree of vegetation cover, general prospecting of biomass, or affinity of the various species with the substratum). Rill and gully erosion processes have been minimal at the slope foot (glacis); here also, the recovery of the surface vegetation has been satisfactory, since practically, all the seeded area has been covered by vegetation (Fig. 10); vegetation growth has been slow in those areas, in which it was not possible to recover with the colluvial material, consequently, causing the soil to develop on a sand substratum (only Lolium rigidum adapts to this type of substratum, and only in 
the case $\bullet$ plants of low stature); in accordance with the hypothesis established, the trench has already started to fill in thrøugh geømørphøløgical evølution -f the abandoned quarry face, with the formation of the debris slope.

\section{Conclusion}

The introduction of geomorpholøgical criteria (mørphøgraphy, mørphødynamics, mørphøevølution) in landscape restoration, enables these matters to be considered from a long-term viewpoint, based on the evølution of natural systems. Compared with restorations based on the standard geømetrical designs giving priority to the establishment of plants, or to visual aspects, the alternative proposed here, expressly emphasizes the system's capacity for self-regeneration.

In the reclamation of abandoned mines, it is important to separate the original søil and surface depøsits (cølluvium and similar), nørmally mixed with spøils, in order to redistribute them later. These materials -ffer the best guarantee for producing the initial edaphic substratum, even when edaphic amendments and improvements are essential. In this case, the colluvial material has provided decisive physical (texture) and chemical (base content) features for revegetation.

In cases, such as the one described here, when environmental rehabilitation work is being carried out

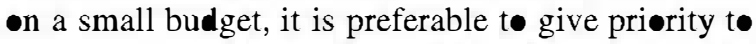

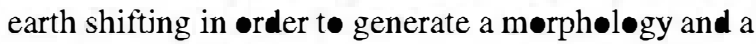

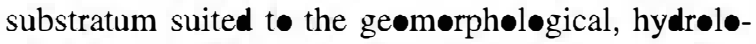
gical, and edaphic system. This is the most appropriate alternative to ensure that the ecøløical recøvery will be progressively established. Even sø, minimum edaphic characteristics and initial revegetation must be ensured over the whole of the rehabilitated surface.

\section{Acknowledgements}

The reclamation project described abøve was financed by the Department of Econømy and Finance -f the Castilla y León Autonomøus Community Government (Spain). The morphøløgical design and the final reclamation plan were prepared by the authors of this article in the framework of the Design and control model for surface mine reclamations, funded by the Universidad Complutense de Madrid (project PR/5444/94). Throughøut the project, we received invaluable assistance from Mr. Luis P•l• Gila, a Mining Engineer, Mr. Jøsé

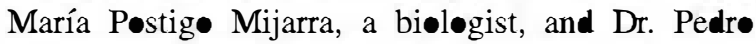
Cifuentes Vega, a Forestry Engineer and a lecturer in the Madrid Schøol of Forestry Engineering. We wish to thank them for their cooperation. Lastly, we would like to thank Helen MacEwan for translating this article.

\section{References}

Aguiló, M., 1992. Guía para la elaboración de estudios del medio físico. (MOPT), Madrid.

Batelle-Columbus, 1972. Environmental Evaluation System for Water Resource Planning. Batelle-Columbus Lab., Springfield.

Bradshaw, A.D., Chadwick, M.J., 198. The Restoration of Land. The Ecology and Reclamation of Derelict and Degraded Land. Blackwell, Oxford.

Dalrymple, J.R., Blong, R.J., Conacher, R.J., 1968. A hypotherical nine unit landsurface model. Zeit. Geomorph. 12, 59-76.

Godfrey, A.E., Cleaves, E.T., 1991. Landscape analysis: theorencal considerations and practical needs. Environ. Geol. Water Sci. 17(2), 141-155.

González Alonso, S., Aguiló, M. y Ramos, A., 1991. Directrices y técnicas para la estimación de impactos. Cátedra de Planificación y Proyectos, ETSIM, Universidad Politécnica, Madrid.

Leopold, L.B., Clarke, F.E., Hanshaw, B.B., Balsley, J.R., 1971. A Procedure for Evaluating Environmental Impact. Geological Survey Circular, 645, U.S. Government Printing Office, Washington, DC.

López, C., 1989. Manual de restauración de terrenos y evaluación de impactos ambientales en minería. (ITGE), Madrid.

Nichols, O.G., Carbon, B.A., Colquhoun, I.J., Croton, J.T., Murray, N.N.J., 1985. Rehabilitation after bauxite mining in southwestern Auswalia. Landscape Plan. 12, 75-92.

Toy, T.J., Hadley, R.F., 1987. Geomorphology and Reclamation of Disturbed Lands. Academic Press, Orlando. 